\title{
INTEGRATING MEDIA DIDACTIC COMPETENCES IN PSYCHOLOGY COURSES OF TEACHER EDUCATION
}

\author{
Sarah Lukas, Anna-Lisa Max and Holger Weitzel \\ Pädagogische Hochschule Weingarten \\ Kirchplatz 2, 88250 Weingarten, Germany
}

\begin{abstract}
Internationally, ICT have become an integral part of school curricula in recent years. As a consequence, teacher education has the aim of imparting the necessary knowledge for the effective use of ICT. The TPACK framework is a frequently used theoretical basis to achieve this goal. In our study we investigate to what extent TPACK is promoted in a psychology course and how TPACK development correlates with other aspects of professional teachers. Results show that educational psychology courses can promote TPACK and that aspects of motivation or comprehension of constructivist learning settings should be considered in the conceptualization of courses with the aim to promote TPACK.
\end{abstract}

\section{KEYWORDS}

TPACK, ICT, Educational Psychology, Teacher Education, Motivation, Constructivist Learning Settings

\section{INTRODUCTION}

Psychology courses play an important role in teacher education. Traditional educational psychology includes issues like learning, development, motivation, classroom management, and assessment. However, in the recent years, also media psychological expertise becomes more and more important in teacher curricula, as the use of digital media for teaching and learning (ICT) is increasingly discussed (e. g., Gmundusdottir \& Hatlevik, 2018). This development is reflected in research and set down in competence guidelines for teacher education (e.g. USDE, 2017, Redecker, 2017). Internationally, the TPACK framework (Mishra \& Koehler, 2006, 2008) has received increasing attention for describing the knowledge teachers need to effectively integrate ICT into classroom teaching (e.g. Chai, Koh \& Tsai, 2016; Rocha Fernandes et al., 2020). The TPACK framework defines seven technology-related knowledge domains, which extend subject knowledge and pedagogical knowledge as central dimensions of teacher knowledge by the technological aspect. TPACK describes the knowledge and skills required to teach the content of a subject in a didactically and pedagogically appropriate manner by means of ICT (Fig. 1). TPACK thus represents a context-related synthesis of teachers' professional knowledge for teaching domain-specific content through the use of digital technologies. Developing TPACK among teachers is considered a long-term process (Hofer \& Grandgenett, 2012) that can take place in different areas of teacher education and is influenced by other variables such as the students' comprehension of constructivist learning settings (CCL), self-efficacy (Valtonen et al., 2020), and motivation (Holland \& Piper, 2014). 


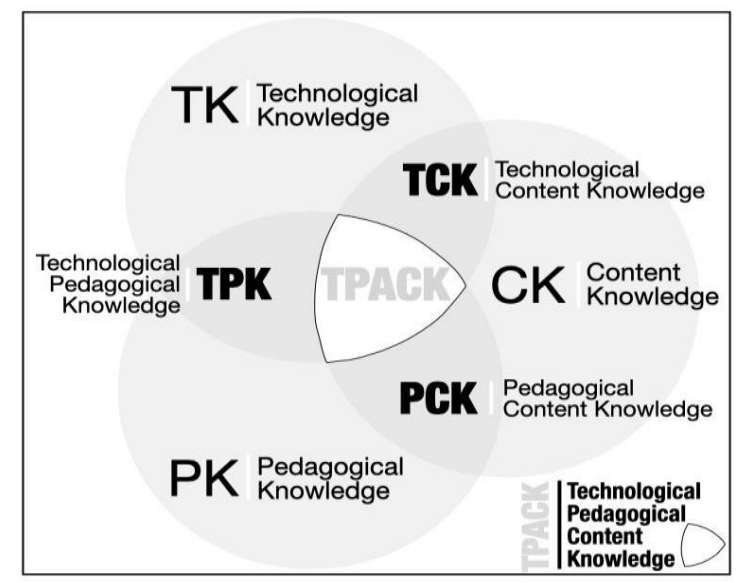

Figure 1. The TPACK model (own depiction, adapted from Koehler \& Mishra, 2009)

With educational psychology being an important topic in teacher education and including media psychology as a rather recent important part of the discipline (for the current discussion see for instance Edling \& Liljestrand, 2020), we argue here that psychology courses in preservice teacher education can be effectively used to convey TPACK, at least to a certain extent. It is not within the scope of psychology courses in teacher education to convey content knowledge and didactics. Hence, the C component of TPACK cannot be fully addressed in psychology courses and probably, rather TPK is developed. Lachner et al. (2019) suggested that for TPK especially pedagogic knowledge was important, which is in line of our hypothesis that educational psychology courses can effectively improve TPK/TPACK. Specifically, modern educational psychology includes media pedagogic contents. Accordingly, issues of the traditional educational psychology (like motivation) are intertwined with the modern media psychology (like how digital media can be used to improve motivation). Hence, we hypothesize that educational psychology courses can be important to convey TPACK. In the following, we will present an example of how this could be done and how the development of TPACK within one semester is changed in a psychology class of master teacher education. We additionally gathered data of motivation, self-efficacy with respect to using technology, and CCL, because the use of digital media can provide constructivist learning environments and it has been shown that constructivist beliefs correlate with use of computers in the classroom (Hermans et al., 2008).

\section{METHOD}

\subsection{Course Content}

The course in which this study was conducted was part of the project TPACK 4.0, which has the aim to foster TPACK in preservice teacher students. To this end, a TPACK-input was created and implemented in the teacher courses. The TPACK-input was based on the TPACK model, the DigCompEdu framework (Redecker, 2017), the Substitution Augmentation Modification Redefinition (SAMR) Model (Hamilton et al., 2016), principles of multimedia learning (Mayer, 2009), as well as criteria for good quality teaching (Steffensky \& Neuhaus, 2018). The course "Visualisation of cognitive psychological theories" contained cognitive-psychological theories which might be relevant for teacher students (e.g., the working memory model, Baddeley, 2002; Language and simulation in conceptual processing, Barsalou et al., 2008). Each working group processed one self-selected theory by reading the basic literature and transferred it into the creation of a digital media teaching unit. Most of the students chose to create an explanatory video, but one group also decided to design an AR worksheet. Due to the Covid-19 pandemia, the TPACK-input as well as the other course units had to take place online. Also the creation of the teaching media, which were foreseen to be conducted in the pedagogical makerspace CoLiLab (see for further details Lukas et al., 2019; Max et al., 2020) had to take place at home. 


\subsection{Questionnaire}

The pre-post questionnaire was developed on the basis of standardized scales in order to measure the influence of working on psychology related media projects in terms of TPACK (Schmidt et al. 2009; Handal et al. 2013) as well as in terms of the construct's intrinsic motivation (Wilde et al., 2009) and self-efficacy (Holden \& Rada, 2011). Moreover, we collected data of the students' CCL. TPACK was measured with 13 items, which tested self-assessment of TPACK. The scale could be ranked between one and four. Motivation was tested with 12 items, ranging between one and five. Self-efficacy concerning the use of technology and digital was measured with ten items, ranging from one to four. CCL was tested with 12 items, ranging from one until four. The pretest was conducted at the beginning of the summer semester 2020 (march - july), the posttest was conducted at the end of this semester.

\subsection{Sample}

The sample consisted of 50 participants (male $=7$; female $=40$; not reported $=3$ ) of a master's degree course in educational psychology. This course is a compulsory elective subject within the framework of their further basic-education-program, regardless of their chosen teaching subjects and later teaching level (primary or secondary school). Of the 50 participants, not all completed the pre- as well as the posttest. In some cases it was due to a dropout of the course. Only those who completed both questionnaires were included in the analysis, which resulted in a sample of 23 participants (male $=3$; female $=20$ ). Age ranged between 21 and 45 years, with a mean of $M=24$.

\subsection{Reliability Analysis}

We measured reliability of the scales TPACK, motivation, CCL and self-efficacy of the pretest. Reliability of TPACK was $\alpha=.88$, of motivation $\alpha=.88$, of constructivist learning settings $\alpha=.67$, and of self-efficacy $\alpha=.66$. It can be rated as good for TPACK and motivation, but as rather dubious for CCL and self-efficacy.

\section{RESULTS}

First, the development of TPACK during the course was analyzed. The mean rating of the TPACK pretest was $M=2.59$ and of the posttest $M=2.9$. A t-test revealed that TPACK increased significantly during the semester, $t(22)=2.91, \mathrm{p}=.008$. With Cohen's $d_{z}=.6$, effect size was medium high. None of the other variables changed significantly in the respective timeframe (see Table 1 for the means of the pre- and posttest, respectively).

In a second step, we conducted a correlation analysis of the variables TPACK, motivation, CCL and self-efficacy. TPACK correlated significantly positive with motivation in the pretest $(r=.48, p=.001)$, and even more in the posttest $(r=.64, p<.001)$. Interestingly, TPACK correlated significantly negative with CCL in the pretest $(r=-.31, p=.036)$. This correlation vanished in the posttest $(r=-.31, p=0.12)$. There was no significant correlation between TPACK and self-efficacy.

Table 1. Means and standard deviation (in brackets) of the measured constructs TPACK, motiviation, self-efficacy and students' comprehension of constructivist learning settings (CCL) in the pre- and posttest

\begin{tabular}{lllll}
\hline & TPACK & Motivation & Self-efficacy & CCL \\
\hline Pretest & $2.59(0.32)$ & $3.47(0.49)$ & $2.03(0.33)$ & $2.81(0.31)$ \\
\hline Posttest & $2.9(0.48)$ & $3.4(0.58)$ & $2.1(0.29)$ & $2.82(0.4)$ \\
\hline
\end{tabular}




\section{DISCUSSION}

The aim of the study was to examine if educational psychology courses in teacher education can convey TPACK. Indeed, a significant increase of TPACK was found during the course. Integrating TPACK contents in educational psychology courses in teacher education seems to be successful for the development of TPACK. As a result, TPACK/TPK components should be integrated in educational psychology curricula in teacher education. Earlier findings were confirmed by showing a significant correlation between intrinsic motivation and TPACK. By developing courses with the aim to convey TPACK, the activation of intrinsic motivation of the learners should be taken into account. In the pretest an unexpected negative correlation between TPACK and CCL was found. This suggests that although student's might have a comprehension of constructivist learning settings, they were not able to clearly connect it with TPACK. This issue should be addressed in future TPACK courses as well.

Please note that the described psychology course rather addressed the TPK component, but the result in TPACK was measured. For a better understanding of the correlations between TPK and TPACK, and how teaching TPK is reflected in TPACK, further studies have to be conducted.

\section{CONCLUSION}

The presented study clearly shows promising indication that educational psychology courses can promote TPACK in teacher students. Given that developing TPACK is a long-term process and acquires various experience possibilities, it should be integrated interdisciplinarily in the teacher education and also be transferred by the basic subjects of educational sciences. The presented study is only a small part of the still ongoing project TPACK 4.0 and can thus only address limited aspects of a bigger picture. But it provides indications of the importance of educational psychology and its adaptation regarding ongoing debates and developments.

\section{ACKNOWLEDGEMENT}

This project is funded by the Ministry of Science, Research and Arts, Ministerium für Wissenschaft, Forschung und Kunst, Baden-Württemberg, digital@bw, Az.: 43-6700.-4/2/1/1.

\section{REFERENCES}

Baddeley, A. D., 2002. Is working memory still working? European Psychologist, 7, pp. 85-97.

Barsalou, L. W., Santos, A., Simmons, W. K., \& Wilson, C. D., 2008. Language and simulation in conceptual processing. In: M. de Vega, A. Glenberg \& A. Graesser (Eds.) Symbols and embodiment debates on meaning and cognition. Oxford University Press, Oxford, pp. 245-284. doi:10.1093/acprof:oso/9780199217274.003.0013.

Chai, C. S., Koh, J. H. L., \& Tsai, C.-C. (2016). A Review of the Quantitative Measures of Technological Pedagogical Content Knowledge (TPACK). In M. Herring, P. Mishra, \& M.J. Koehler (Eds.). Handbook of technological pedagogical content knowledge (TPCK) for educators (second edition), Routledge, New York, pp. 87-106.

Edling, S., Liljestrand, J., 2020. Let's talk about teacher education! Analysing the media debates in 2016-2017 on teacher education using Sweden as a case. Asia-Pacific Journal of Teacher Education, 48, pp. 251-266. https://doi.org/10.1080/1359866X.2019.1631255

Gudmundsdottir, G.B., Hatlevik, O.E., 2018. Newly qualified teachers' professional digital competence: implications for teacher education. European Journal of Teacher Education, 41, pp. 214-231. https://doi.org/10.1080/02619768.2017.1416085

Hamilton, E.R., Rosenberg, J.M., Akcaoglu, M., 2016. The Substitution Augmentation Modification Redefinition (SAMR) Model: A critical review and suggestions for its use. TechTrends, 60, pp. 433-441. https://doi.org/10.1007/s11528016-0091-y

Handal, B., Campbell, C., Cavanagh, M., Petocz, P., \& Kelly, N., 2013. Technological Pedagogical Content Knowledge of Secondary Mathematics Teachers. Contemporary Issues in Technology and Teacher Education, 13(1), pp. 22-40 
Hermans, R., Tondeur, J., van Braak, J., Valcke, M., 2008. The impact of primary school teachers' educational beliefs on the classroom use of computers. Computers \& Education 51, pp. 1499-1509. https://doi.org/10.1016/j.compedu.2008.02.001

Hofer, M., Grandgenett, N., 2012. TPACK Development in Teacher Education: A Longitudinal Study of Preservice teachers in a Secondary M.A.Ed Program. Journal of Research on Technology in Education, 45(1), pp. 83-106.

Holden, H., \& Rada, R. (2011). Understanding the Influence of Perceived Usability and Technology Self-Efficacy on Teachers' Technology Acceptance. Journal of Research on Technology in Education, 43(4), pp. 343-367. https://doi.org/10.1080/15391523.2011.10782576

Holland, D.D., Piper, R.T., 2014. A Technology Integration Education (Tie) Model: Millennial Preservice Teachers' Motivations about Technological, Pedagogical, and Content Knowledge (Tpack) Competencies. Journal of Educational Computing Research 51, pp. 257-294. https://doi.org/10.2190/EC.51.3.a

Koehler, M.J., Mishra, P., 2009. What is Technological Pedagogical Content Knowledge? Contemporary Issues in Technology and Teacher Education 9, pp. 60-70.

Lachner, A., Backfisch, I., \& Stürmer, K. (2019). A test-based approach of Modeling and Measuring Technological Pedagogical Knowledge. Computers \& Education, 142, 103645. https://doi.org/10.1016/j.compedu.2019.10364

Lukas, S., Müller, W., Huwer, J., Drüke-Noe, C., Koppel, I., Rebholz, S., Stratmann, J., Theilmann, F., Weitzel, H., 2019. Improving students' TPACK through learning labs: The implementation of IChemLab and STEAM Makerspace. EDULEARN2019 Proceedings, Palma, Spain, pp. 6718-6726. https://doi.org/10.21125/edulearn.2019.1611

Max, A.L., Schmoll, I., Uhl, P., Huwer, J., Lukas, S., Mueller, W., Weitzel, H., 2020. Integration of a teaching-learningn lab and a pedagogical makerspace into a module for media education for STEAM teacher students, INTED2020 Proceedings. Valencia, Spain, pp. 2050-2059. https://doi.org/10.21125/inted.2020.0645

Mayer, R.E., 2009. Multimedia Learning, 2nd ed. Cambridge University Press, Cambridge. https://doi.org/10.1017/CBO9780511811678

Mishra, P., Koehler, M.J., 2008. Introducing Technological Pedagogical Content Knowledge. Presented at the Annual Meeting of the American Education Association, pp. 1-16.

Mishra, P., Koehler, M.J., 2006. Technological Pedagogical Content Knowledge: A Framework for Teacher Knowledge. Teachers College Rec 108, pp. 1017-1054. https://doi.org/10.1111/j.1467-9620.2006.00684.x

Redecker, C., 2017. European Framework for the Digital competence of educators. DigCompEdu. (Policy Report No. EUR 28775 EN). Publication Office of the European Union, Luxembourg.

Rocha Fernandes, G.W., Rodrigues, A.M., \& Ferreira, C.A. (2020). Professional Development and Use of Digital Technologies by Science Teachers: a Review of Theoretical Frameworks. Res Sci Educ 50, pp. 673-708.

Schmidt, D.A., Baran, E., Thompson, A.D., Mishra, P., Koehler, M.J., Shin, T.S., 2009. Technological Pedagogical Content Knowledge (TPACK): The Development and Validation of an Assessment Instrument for Preservice Teachers. Journal of Research on Technology in Education 42, pp. 123-149.

Steffensky, M., \& Neuhaus, B. J., 2018. Unterrichtsqualität in der naturwissenschaftlichen Forschung. In D. Krüger, I. Parchmann, \& H. Schecker (Eds.) Theorien in der naturwissenschaftsdidaktischen Forschung, Springer, Berlin, pp. 299-313.

U.S. Department of Education (2017). Reimagining the role of technology in higher education: A supplement to the National Education Technology Plan. Washington, D.C.: Office of Educational Technology. Retrieved July 20, 2020 from https ://tech.ed.gov/files /2017/01/Highe r-Ed-NETP.pdf.

Valtonen, T., Leppänen, U., Hyypiä, M., Sointu, E., Smits, A., \& Tondeur, J. (2020). Fresh perspectives on TPACK: pre-service teachers' own appraisal of their challenging and confident TPACK areas. Educ Inf Technol 25, pp. 2823-2842.

Wilde, M., Bätz, K., Kovaleva, A., \& Urhahne, D. (2009). Überprüfung einer Kurzskala intrinsischer Motivation (KIM). ZfDN, 15, pp. 31-45. 